International Journal of Business Management and Economic Review

Vol. 4, No. 06; 2021

ISSN: 2581-4664

\title{
LINKING ORGANIZATIONAL CULTURE, EMOTIONAL INTELLIGENCE AND JOB SATISFACTION TO ORGANIZATIONAL COMMITMENT
}

\author{
Cherly Kemala Ulfa $^{{ }^{*}}$, Ari Juliana ${ }^{2}$ and Aulia Keiko Hubbansyah ${ }^{3}$ \\ 1Universitas Terbuka \\ 2Universitas Terbuka \\ 3Universitas Pancasila
}

http://doi.org/10.35409/IJBMER.2021.3321

\begin{abstract}
Since e-learning has become a trend in the Covid-19 pandemic period in Indonesia, Indonesia Open University has found at least 4000 new competitors in the country, grown for four months. To survive sustainably as a pioneer in distance learning in Indonesia, Open University needs to identify one source of organizational strength to deal with change and competition: the organization's internal source, namely the organizational commitment. This study aims to investigates the effect of organizational culture, emotional intelligence and job satisfaction on Indonesia Open University lecturers' organizational commitment. The study involved 130 lecturers working in the head office and supporting units operating throughout Indonesia. The findings show that organizational culture, emotional intelligence, and job satisfaction are positively and significantly related to organizational commitment. This research also becomes empirical evidence that organizational commitment can improve by strengthening organizational culture, emotional intelligence, and job satisfaction among Open University lecturers.
\end{abstract}

Keyword: Organizational Commitment, Organizational Culture, Emotional Intelligence, Job Satisfaction, Open University.

\section{INTRODUCTION}

C-19 pandemic spread disruption to every aspect of our lives. During this pandemic, e-learning became a solution in education so that it will continue to run as usual. As a pioneer of distance higher education in Indonesia, Open University suddenly faces at least 4000 new competitors in Indonesia who have been developing for four months. Competition has occurred. To survive, Open University must respond to these changes quickly and adaptively.

To survive sustainably as a pioneer in distance learning in Indonesia, organizations must know in advance their internal strengths to respond faster. One of the inner forces of an organization, which is a distinguishing capacity that can be an essential point of its competitive advantage, is the organizational commitment (Beer, 2009).

Following the concept of high commitment high-performance organization forward by Beer (Beer et al., 2009), commitment and performance are two ingredients that are essential for the sustainability of the organization. From the various studies he has done on many large organizations, commitment is an absolute prerequisite. Organizational commitment can be interpreted as the level of employee self-identification of the organization and its desire to continue active participation (Radosavljevic, Cilerdzic, \& Dragic, 2017). Organizational commitment can 


\section{International Journal of Business Management and Economic Review}

Vol. 4, No. 06; 2021

ISSN: 2581-4664

also be interpreted with a strong desire from employees to remain members of the organization, a passion for providing high-level business on behalf of the organization, and a strong desire to accept organizational values and goals (Eisenberger, Fasolo, \& Davis-LaMastro, 1990) 2008). In an academic atmosphere, lecturers are a critical element in the teaching and learning process in higher education. Lecturers are professional educators and scientists with the main task of transforming, developing, and disseminating knowledge. As distance educators, Open University lecturers have a significant administrative workload and carry the Higher Education Tridharma (Teaching, Research, and Community Service). There is a uniqueness in Open University lecturers' assignment, where most of the working time is spent handling administrative tasks.

They must carry the management tasks of Higher Education, for example, in the field of teaching or Tutorial Lecturers must look-for tutors, administer tutor data, train and assist tutors, managing abundance work of related administration. It is done continuously to become work behaviour and habits that are part of the Open University's organizational culture. Regarding Open University lecturers, these high administrative work conditions can reduce opportunities to improve academic competence or knowledge related to the field of science. Open University lecturers rarely have the chance to develop their knowledge and expertise, so that the development of capacity and capability in the form of actualizing potential is minimal. This can be a negative work experience and could be a corrosive factor to Open University's lecturers' commitment to their organization. The level of organizational commitment of lecturers tends to below. In this regard, this study intends to analyze the condition of Open University lecturer's commitment and how other variables, like organizational culture, emotional intelligence, and job satisfaction, relate to improving organizational commitment.

\subsection{Theoritical Background}

Organizational commitment can be interpreted as the level of employee self-identification of the organization and its desire to continue active participation (Eisenberger et al., 1990). Organizational commitment can also be interpreted with a strong desire from employees to remain members of the organization, the passion for providing high-level business on behalf of the organization, and a strong desire to accept organizational values and goals (N. J. Allen \& Meyer, 1990). Thus, the conceptual commitment of the organization includes three things, namely, first, the involvement of employees themselves in organizational activities; second, acceptance of the organization's values and goals and readiness to strive earnestly on behalf of the organization; third, the desire to maintain membership in the organization (N. J. Allen \& Meyer, 1990). The unit of analysis to be investigated in this study is the lecturer group. Lecturers are professional educators and scientists with the main task of transforming, developing, and disseminating knowledge. Theoretically, highly committed lecturers are characterized by their willingness to work harder. In a sense, they will limit themselves to the implementation of the main tasks or tasks ordered and involve themselves fully into the organization's dynamics(P. Allen et al., 2012).

Lecturers with high organizational commitment tend to have a strong sense of attachment to the organization where they work. It makes lecturers who have high administrative obligation become loyal to the organization where they work. The opposite condition is found in lecturers who are not committed. Uncommitted lecturers have the characteristics of a low level of acceptance of organizational values. This makes the lecturer's attachment to the organization weak. Lecturers with low organizational commitment tend not to involve themselves and become part of the 


\section{International Journal of Business Management and Economic Review}

Vol. 4, No. 06; 2021

ISSN: 2581-4664

organization entirely. Let alone work more than what is the main task, to fulfil their primary duties, lecturers with low levels of organizational commitment have experienced difficulties results in low performance. Thus, lecturers with low organizational commitment will have a regressive or corrosive impact on the organization's progress. In connection with the above, several factors have been proven to influence employee organizations' commitment, in this case, the educator's profession.

First, is the organizational culture (Taghipour \& Dezfuli, 2013). According to Robbins et al. (2009), organizational is the values that are mutually agreed upon by members of the organization that distinguish it from other organizations. The operational aspect of the role of organizational culture is needed to launch organizational activities and help the organization to be able to achieve its objectives. Another factor that has also been empirically found to influence workers' organizational commitment is emotional intelligence (Utami, Bangun, \& Lantu, 2014). According to Robbins \& T, 2011, emotional intelligence refers to a person's ability to detect and manage emotional cues and information. The theory of emotional intelligence assumes that people who can recognize their own emotions and read other people's emotional cues might be more effective in carrying work. In other words, it is believed that people who have an adequate level of emotional intelligence will be able to work more effectively. One other factor that has also been empirically proven to influence organizational commitment is job satisfaction. Job satisfaction is interpreted as a result of positive experiences gained by workers in their work. Conversely, negative experiences will bring up psychological responses to dissatisfaction with work. Workers who are satisfied with their work tend to be more loyal to the organization. This is reflected in the low level of work absenteeism, or working regularly to achieve new achievements. Conversely, workers who are dissatisfied with their work will display sub-optimal work behaviour and even try to leave the organization. The Structure of this research model is as follow

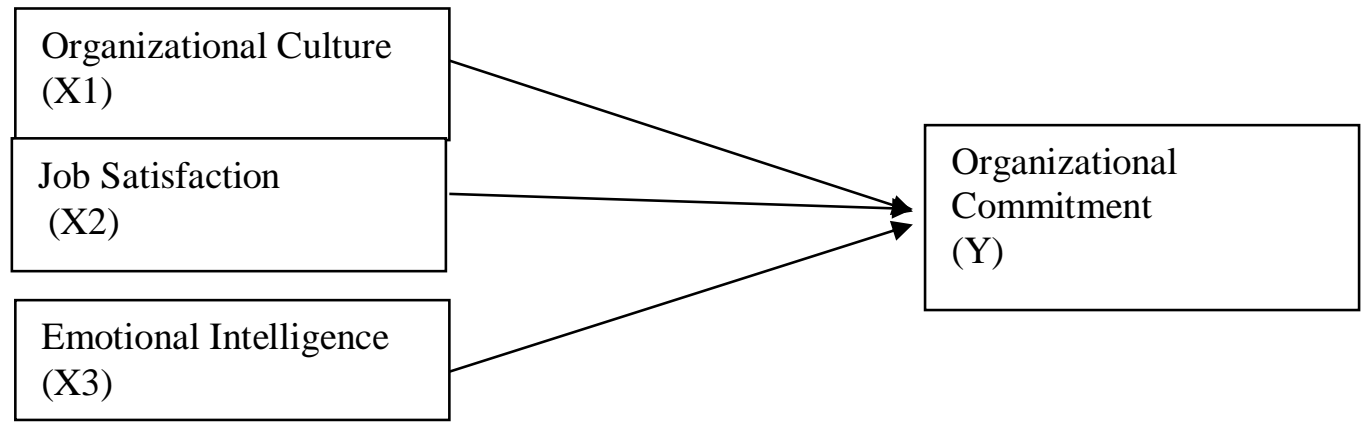

Based on the theoretical descriptions that have been stated previously, this study leads to three main hypotheses. First, organizational culture is positively and significantly related to organizational commitment. Second, there is a positive and significant relationship between job satisfaction and organizational commitment. Finally, the third, emotional intelligence is positively and significantly related to organizational commitment.

\section{METHOD}

This research is a quantitative correlational study which aims to see the relationship and contribution of the dependent variable to the independent variable. Data collection using a 
Vol. 4, No. 06; 2021

ISSN: 2581-4664

questionnaire where the questionnaire given consists of 4 pieces, there is the questionnaire of organizational commitment, job satisfaction, organizational culture and emotional intelligence. The total population of lecturers in Open University working throughout Indonesia is 646 people, but those involved as samples in this study were 130 lecturers from different locations in Indonesia. The sample selection in this study used purposive sampling where the selection of subjects was adjusted to the objectives of this study. Data analysis techniques in this study include descriptive data analysis aimed at finding out the research variables' general characteristics. After discussing descriptive statistics, the test continues to check traditional assumptions, which include tests of normality, heteroscedasticity, and multicollinearity. Furthermore, to obtain information about the general characteristics of the sample, we used descriptive analysis techniques, while to test the hypothesis, we used the F test and the regression test

\section{RESULT AND DISCUSSION}

The research instrument involved measures the variable value of organizational culture, emotional intelligence, job satisfaction, and organizational commitment in a questionnaire with a Likert model scoring. The result of Reliability Testing and Validity Testing in this study are determined as follows:

Table 1. Reliability dan Validity Result

\begin{tabular}{|l|l|l|l|}
\hline No. & List of Questioners & $\begin{array}{l}\text { Cronbach } \\
\text { Alpha Score }\end{array}$ & $\begin{array}{l}\text { Testing of } \\
\text { Validity }\end{array}$ \\
\hline 1. & Organizational Commitment & 0,949 & 29 Valid item \\
\hline 2. & Organizational Culture & 0,957 & 35 Valid Item \\
\hline 3. & Job Satisfaction & 0,948 & 33 Valid Item \\
\hline 4. & Emotional Intelligence & 0,960 & 42 Valid Item \\
\hline
\end{tabular}

Based on the summary above, the measuring instruments developed in this study can be used as the primary research data collection tools.

1. From the results of Descriptive Analysis ;

a. Organizational commitment in this study was measured by 29 statement items with a total of 130 respondents. Associated with descriptive information such as gender, age, education, length of service of the respondent, and functional position, the results of the different test for 
International Journal of Business Management and Economic Review

Vol. 4, No. 06; 2021

ISSN: $2581-4664$

organizational commitment are as follows:

Table 2. Descriptive analysis of Organizational Commitment Variable

\begin{tabular}{|c|c|c|c|c|c|}
\hline Variable & Gender & $\mathbf{N}$ & Mean & F Stat & Sig \\
\hline \multirow{23}{*}{$\begin{array}{l}\text { Organizatio } \\
\text { nal } \\
\text { Commitmen } \\
\mathrm{t}\end{array}$} & Man & 58 & 118 & 0.05 & 0.95 \\
\hline & Woman & 72 & 118 & & \\
\hline & Age & $\mathrm{N}$ & Mean & F Stat & Sig \\
\hline & $21-30$ & 7 & 121 & 1.98 & 0.09 \\
\hline & $31-40$ & 12 & 112 & & \\
\hline & $41-50$ & 19 & 122 & & \\
\hline & $51-60$ & 55 & 117 & & \\
\hline & $61-70$ & 37 & 120 & & \\
\hline & Education & $\mathrm{N}$ & Mean & F Stat & Sig \\
\hline & Magister & 112 & 119 & 1.58 & 0.21 \\
\hline & Doctoral & 18 & 115 & & \\
\hline & $\begin{array}{l}\text { Length of } \\
\text { service/Tenure }\end{array}$ & $\mathrm{N}$ & Mean & F Stat & Sig \\
\hline & $1-10$ & 16 & 117 & 0.50 & 0.73 \\
\hline & $11-20$ & 20 & 119 & & \\
\hline & $21-30$ & 32 & 119 & & \\
\hline & $31-40$ & 59 & 119 & & \\
\hline & $>40$ tahun & 3 & 128 & & \\
\hline & $\begin{array}{l}\text { Functional } \\
\text { Position }\end{array}$ & $\mathrm{N}$ & Mean & F Stat & Sig \\
\hline & Lecturer & 18 & 117 & 0.44 & 0.73 \\
\hline & Senior Lecturer & 69 & 119 & & \\
\hline & Assistant & 35 & 118 & & \\
\hline & Professor & 5 & 123 & & \\
\hline & Professor & & & & \\
\hline
\end{tabular}

From the ANOVA test results, it is known that there is no difference in the average value of lecturers' organizational commitment based on gender, education, years of service, or functional position. Meanwhile, descriptively, there are differences in the average for organizational commitment based on age categories. Among the observed age groups, respondents aged 41-50 years had the highest average organizational commitment, with a score of 122

Organizational culture in this study was measured by 35 statement items with a total of 130 respondents. Associated with descriptive information such as gender, age, education, length of service of the respondent, and functional position, the results of the organizational culture difference test are as follows: 
International Journal of Business Management and Economic Review

Vol. 4, No. 06; 2021

ISSN: 2581-4664

Tabel 3. Descriptive Analysis of Organizational Culture Variable

\begin{tabular}{|c|c|c|c|c|c|}
\hline Variable & Gender & $\mathrm{N}$ & Mean & F Stat & Sig \\
\hline \multirow{22}{*}{$\begin{array}{l}\text { Organizati } \\
\text { onal } \\
\text { Culture }\end{array}$} & Man & 58 & 142 & 0.04 & 0.85 \\
\hline & Woman & 72 & 143 & & \\
\hline & Age & $\mathrm{N}$ & Mean & F Stat & Sig \\
\hline & $21-30$ & 7 & 140 & 2.88 & 0.03 \\
\hline & $31-40$ & 12 & 136 & & \\
\hline & $41-50$ & 19 & 152 & & \\
\hline & $51-60$ & 55 & 141 & & \\
\hline & $61-70$ & 37 & 142 & & \\
\hline & Education & $\mathrm{N}$ & Mean & F Stat & Sig \\
\hline & Magister & 112 & 142 & 0.04 & 0.85 \\
\hline & $\begin{array}{l}\text { Doctoral } \\
\text { Degree }\end{array}$ & 18 & 143 & & \\
\hline & $\begin{array}{l}\text { Length of } \\
\text { service/ Tenure }\end{array}$ & $\mathrm{N}$ & Mean & F Stat & Sig \\
\hline & $1-10$ & 16 & 138 & 1.53 & 0.19 \\
\hline & $11-20$ & 20 & 148 & & \\
\hline & $21-30$ & 32 & 142 & & \\
\hline & $31-40$ & 59 & 141 & & \\
\hline & $>40$ years & 3 & 152 & & \\
\hline & $\begin{array}{l}\text { Functional } \\
\text { Position }\end{array}$ & $\mathrm{N}$ & Mean & F Stat & Sig \\
\hline & Lecturer & 18 & 140 & 0.13 & 0.95 \\
\hline & Senior Lecturer & 69 & 142 & & \\
\hline & Assist. & 35 & 142 & & \\
\hline & Professor & 5 & 143 & & \\
\hline
\end{tabular}

From the results of the Anova difference test, it is known that there is no difference in the average value of the organizational culture of lecturers based on gender, education, years of service, or functional position. Meanwhile, descriptively, there are mean differences in an organizational culture based on age categories. Among the observed age groups, respondents aged 41-50 years had the highest mean score for organizational culture, with scores of 152.

Emotional intelligence in this study was measured by 42 statement items, with a total of 130 respondents. Associated with descriptive information such as gender, age, education, length of service of the respondent, and functional position, the results of the organizational culture difference test are as follows: 
International Journal of Business Management and Economic Review

Vol. 4, No. 06; 2021

ISSN: 2581-4664

Tabel 4. Descriptive Analysis of Emotional Intelligence Variable

\begin{tabular}{|c|c|c|c|c|c|}
\hline Variable & Gender & $\mathbf{N}$ & Mean & F Stat & Sig \\
\hline \multirow{23}{*}{$\begin{array}{l}\text { Emotional } \\
\text { Intelligenc } \\
\mathrm{e}\end{array}$} & Man & 58 & 170 & 0.02 & 0.91 \\
\hline & Woman & 72 & 170 & & \\
\hline & Ages & $\mathrm{N}$ & Mean & F Stat & Sig \\
\hline & $21-30$ & 7 & 171 & 1.13 & 0.35 \\
\hline & $31-40$ & 12 & 166 & & \\
\hline & $41-50$ & 19 & 175 & & \\
\hline & $51-60$ & 55 & 167 & & \\
\hline & $61-70$ & 37 & 171 & & \\
\hline & Education & $\mathrm{N}$ & Mean & F Stat & Sig \\
\hline & Magister & 112 & 170 & 0.20 & 0.65 \\
\hline & $\begin{array}{l}\text { Doctoral } \\
\text { Deoree }\end{array}$ & 18 & 168 & & \\
\hline & $\begin{array}{l}\text { Length } \\
\text { Service }\end{array}$ & $\mathrm{N}$ & Mean & F Stat & Sig \\
\hline & $1-10$ & 16 & 170 & 0.53 & 0.72 \\
\hline & $11-20$ & 20 & 171 & & \\
\hline & $21-30$ & 32 & 169 & & \\
\hline & $31-40$ & 59 & 169 & & \\
\hline & $>40$ years & 3 & 181 & & \\
\hline & $\begin{array}{l}\text { Functional } \\
\text { Position }\end{array}$ & $\mathrm{N}$ & Mean & F Stat & Sig \\
\hline & Lecturer & 18 & 170 & 0.03 & 0.93 \\
\hline & Senior Lecturer & 69 & 169 & & \\
\hline & Assist. & 35 & 169 & & \\
\hline & Professor & 5 & 169 & & \\
\hline & Professor & & & & \\
\hline
\end{tabular}

From the Anova test results, it is known that there is no difference in the average score of lecturers' emotional intelligence based on gender, education, years of service, and functional position. Meanwhile, descriptively, there is a significant difference in the average emotional intelligence based on the working-age category. Among the observed age groups, lecturer respondents aged 41-50 years had the highest average dynamic intelligence score, namely 175; Meanwhile, based on tenure, the group of respondents who had worked more than 40 years had the highest emotional intelligence score 181 .

Job satisfaction in this study was measured by 32 statement items, with a total of 130 respondents. Associated with descriptive information such as gender, age, education, length of service of the respondent, and functional position, the results of the organizational culture difference test are as follows:

Tabel 5. Descriptive Analysis of Job Satisfaction Variable 
International Journal of Business Management and Economic Review

Vol. 4, No. 06; 2021

ISSN: 2581-4664

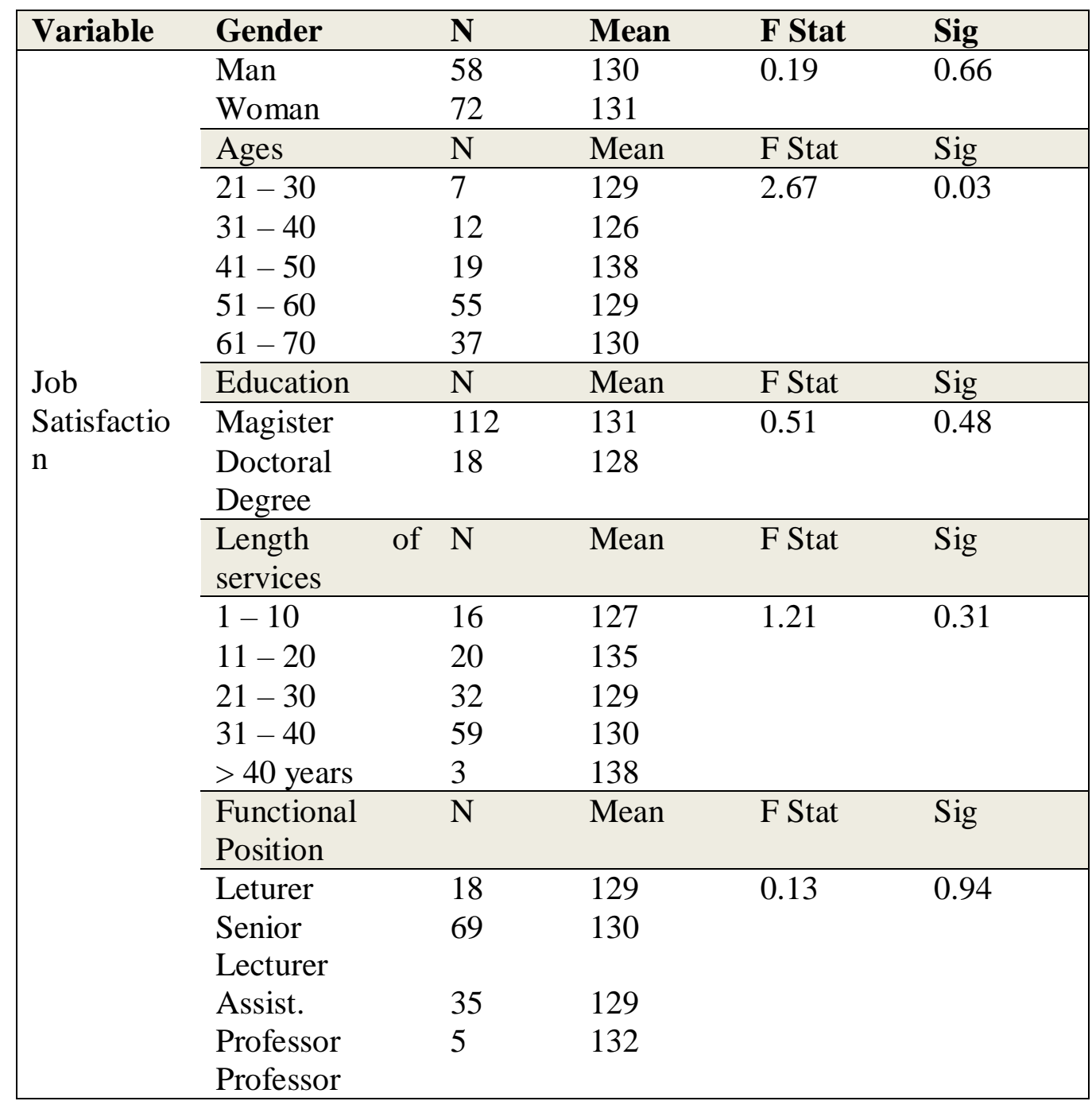

From the results of the Anova difference test, it is known that there is no difference in the average value of lecturers' job satisfaction based on gender, education, years of service, or functional position. Meanwhile, descriptively, there are differences in the average for job satisfaction based on age categories. Among the observed age groups, respondents aged 41-50 years had the highest mean score for organizational culture, with 138 scores.

From different tests with ANOVA, it is known that there is no difference in the average value of commitment of lecturers' organizations based on gender, education, tenure, or functional position. The difference is only in the age category, which is among the age groups observed, respondents aged 41-50 years had the highest average of organizational commitment scores. This result occurs consistently in organizational culture variables, emotional intelligence, and job satisfaction where the age category of $41-50$ years is the age group with the highest average score for each variable.

\subsection{Result of Assumption Analysis}


International Journal of Business Management and Economic Review

Vol. 4, No. 06; 2021

ISSN: 2581-4664

a. Normality Test

The normality test is intended to determine whether the standardized residual values in the regression model are normally distributed or not. The residual value is normally distributed if the standardized residual value is mostly close to the average value.

Tabel 6. Result of Test of Normality

\begin{tabular}{|lll|}
\hline & & Standardized Residual \\
\hline $\mathrm{N}$ & Mean & 130 \\
Normal Parameter & Std. Deviation & 0.000 \\
& Absolute & 8.469 \\
Most Extreme Differences & \\
& Positive & \\
& Negative & \\
Kolmogorov-Smirnov Z & & 0.886 \\
Asymp. Sig. (2-tailed) & & 0.412 \\
\hline
\end{tabular}

Based on the tests' results, a significance value (2-tailed) of 0.412 (greater than 5 per cent) was obtained. Therefore, $\mathrm{H} 0$ (normal residual distribution) cannot be rejected. It can be stated that the residual value of the model estimate is spread normally.

b. Multicollinearity Test

The multicollinearity test aims to test whether there is a high or perfect correlation between the independent variables or not in the regression model that is formed. Suppose in the regression model that is formed there is a high or perfect correlation between the independent variables. In that case, the regression model is stated to contain multicollinear symptoms, so the estimation tends to be biased. For this reason, to obtain good estimation results, so that the decision-making can be more accurate, it is necessary to test the variables' multicollinearity conditions.

Table 7. Independent Intervariable Correlation Research

\begin{tabular}{|l|llll|}
\hline \multicolumn{2}{|c}{} & OC & EI & JS \\
\hline OC & Pearson Correlation & 1 & 0.584 & 0.782 \\
EI & Pearson Correlation & 0.584 & 1 & 0.612 \\
JS & Pearson Correlation & 0.782 & 0.612 & 1 \\
\hline
\end{tabular}

From the multicollinearity test, it is known that the correlation value between independent variables in this study does not exceed 0.80 . This means that there is no multicollinearity evidence between one independent variable and another in the formed regression model.

c. Heteroscedasticity Test

A heteroscedasticity test was conducted to identify whether there were variants of the variables in the regression model that was not constant. This needs to be known because it can affect the estimation results of the model. In this case, a model containing heteroscedasticity constraints tends to produce biased estimates. Therefore, it is crucial to perform this test to ensure that the resulting model estimates are unbiased and consistent. The heteroscedasticity test in this study used the Glejser Test approach. The test results are as follows: 
International Journal of Business Management and Economic Review

Vol. 4, No. 06; 2021

ISSN: 2581-4664

Tabel 8. Result of Gletjser Test

\begin{tabular}{|c|c|c|c|c|c|c|}
\hline \multirow{2}{*}{\multicolumn{2}{|c|}{ Model }} & \multicolumn{2}{|c|}{$\begin{array}{l}\text { Unstandardized } \\
\text { Coefficients }\end{array}$} & \multirow{2}{*}{ 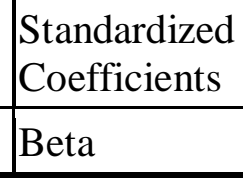 } & \multirow[b]{2}{*}{$\mathrm{t}$} & \multirow[b]{2}{*}{ Sig. } \\
\hline & & B & Std. Error & & & \\
\hline 1 & (Constant) & .275 & 6.094 & & .045 & .964 \\
\hline & OC & -.004 & .003 & -.189 & -1.338 & .183 \\
\hline & EI & .001 & .003 & .034 & .305 & .761 \\
\hline & JS & -.003 & .004 & -.116 & $\mid-.799$ & .426 \\
\hline
\end{tabular}

a. Dependent Variable: RES

Based on the Glejser test, it can be seen that both the variables OC, JS, and EI are not significant to the absolute unstandardized residual model. Therefore, it can be concluded that there are no symptoms of heteroscedasticity in this research model.

\section{Model Estimation Results}

This section will discuss the results of the research model estimation. The aim is to prove whether the test hypothesis suspected in this study can be proven empirically. However, previously some defining aspects of the estimation results of the research model will be described as follows:

Tabel 9. Summary of Research Models

\begin{tabular}{|l|l|l|l|l|}
\hline Model & $R$ & R Square & $\begin{array}{l}\text { Adjusted } \\
\text { Square }\end{array}$ & $\begin{array}{l}\text { Rtd. An error } \\
\text { of the } \\
\text { Estimate }\end{array}$ \\
\hline 1 & $.706^{\mathrm{a}}$ & .500 & .487 & 8.50939 \\
\hline
\end{tabular}

a. Predictors: (Constant), JS, EI, OC

In general, the models built and estimated in this study have the ability to explain variations in organizational commitment variables well as shown by the R-square model value, which reaches 0.500. This means that the variables of organizational culture, job satisfaction, and emotional intelligence used in this study, together, can explain 50.0 per cent of the variation in the organizational commitment of the lecturers who are the object of the study.

Tabel 10. Result of The F-Test

\begin{tabular}{|c|c|c|c|c|c|c|}
\hline \multicolumn{2}{|c|}{ Model } & $\begin{array}{l}\text { Sum } \\
\text { Squares }\end{array}$ & df & Mean Square & $\mathrm{F}$ & Sig. \\
\hline \multirow[t]{3}{*}{1} & Regression & 9217.670 & 3 & 3072.557 & 41.854 & $.000^{\mathrm{a}}$ \\
\hline & Residual & 9254.191 & 126 & 73.016 & & \\
\hline & Total & 18471.861 & 129 & & & \\
\hline
\end{tabular}



a. Predictors: (Constant), JS, EI, OC
b. Dependent Variable: OCm

Also, based on the results of the $\mathrm{F}$ test, it is known that these three variables together have a significant effect on the commitment organization of the lecturer. This is indicated by the model's F-Stat value, which reaches 41,854 with a degree of significance less than 1 per cent. Therefore, it can be stated that these three variables have a role as a determinant factor that can determine the level of organizational commitment to lecturers.

4. Hypothesis Test Results

a. The first hypothesis in this study states that organizational culture variables have a positive and significant influence on lecturers' organizational commitment. In this case, the hypothesis being tested is:

$\mathrm{H} 0$ : $\rho \mathrm{y}, \mathrm{x} 1=0$

$\mathrm{H} 1: \rho \mathrm{y}, \mathrm{x} 1 \neq 0$

$\mathrm{HO}$ is rejected if $\mathrm{t}$-count is found to be greater than t-table

Tabel 11. The results of the significant coefficient test of the influence of $X 1$ on $Y$

\begin{tabular}{|c|c|c|c|c|c|}
\hline \multirow[b]{2}{*}{ Influence } & \multirow{2}{*}{$\begin{array}{l}\text { United. } \\
\text { Koefesien }\end{array}$} & \multirow[b]{2}{*}{$\mathrm{t}$-count } & \multicolumn{3}{|l|}{ t-table } \\
\hline & & & $\begin{array}{ll}10 & \text { per } \\
\text { cent }\end{array}$ & $\begin{array}{l}5 \text { per } \\
\text { cent }\end{array}$ & $\begin{array}{l}1 \\
\text { percent }\end{array}$ \\
\hline $\mathrm{X} 1$ on $\mathrm{Y}$ & 0.288 & $\begin{array}{l}3.474 * * \\
*\end{array}$ & 1.66 & 1.98 & 2.62 \\
\hline
\end{tabular}

Information: $* * *=$ very significant at the 1 percent level

Table 11 above shows that the coefficient value of organizational culture on lecturer organizational commitment is 0.288 with a $t$-count of 3.474 , which is greater than the $t$-table value for the 1 per cent significance level 2.62. Because the t-table value is greater than the $t$-count value, $\mathrm{H} 0$ is rejected, which means that organizational culture has a positive and significant influence on the lecturers' commitment organization at the Open University in Indonesia.

b. The second hypothesis in this study states that the job satisfaction variable has a positive and significant influence on lecturers' organizational commitment. In this case, the hypothesis being tested is:

$\mathrm{H} 0: \rho \mathrm{y}, \mathrm{x} 2=0$

$\mathrm{H} 1: \rho \mathrm{g}, \mathrm{x} 2 \neq 0$

$\mathrm{H} 0$ is rejected if the $\mathrm{t}$-count is found to be greater than the $\mathrm{t}$-table.

Tabel 12. The results of the significant coefficient test of the influence of $X 2$ on $Y$ 


\section{International Journal of Business Management and Economic Review}

Vol. 4, No. 06; 2021

ISSN: 2581-4664

\begin{tabular}{|c|c|c|c|c|c|}
\hline \multirow[b]{2}{*}{ Influence } & \multirow{2}{*}{$\begin{array}{l}\text { Unstd. } \\
\text { Coefesien }\end{array}$} & \multirow[b]{2}{*}{$\mathrm{T}_{\text {count }}$} & \multicolumn{3}{|l|}{$\mathrm{t}$-table } \\
\hline & & & $\begin{array}{ll}10 & \text { per } \\
\text { cent }\end{array}$ & $\begin{array}{l}5 \text { per } \\
\text { cent }\end{array}$ & $\begin{array}{l}1 \\
\text { percent }\end{array}$ \\
\hline $\mathrm{X}_{2}$ on $\mathrm{Y}$ & 0.230 & $\begin{array}{l}3.229 * \\
* *\end{array}$ & 1.66 & 1.98 & 2.62 \\
\hline
\end{tabular}

Information: $* * *=$ very significant at the 1 percent level

Table 12 above shows that the coefficient value of job satisfaction on lecturer organizational commitment is 0.230 with a $t$-count value of 3.229 , which is greater than the $t$-table value for the 1 per cent significance level, score 2.62. Because the t-table value is greater than the $t$-count value, $\mathrm{HO}$ is rejected, which means that job satisfaction has a positive and significant effect on the commitment of the Open University lecturers in Indonesia.

c. The third hypothesis in this study states that the emotional intelligence variable has a positive and significant effect on lecturers' organizational commitment. In this case, the hypothesis being tested is:

$\mathrm{H} 0$ : $\rho \mathrm{y}, \mathrm{x} 3=0$

$\mathrm{H} 1: \rho \mathrm{g}, \mathrm{x} 3 \neq 0$

$\mathrm{H} 0$ is rejected if the $\mathrm{t}$-count is found to be greater than the $\mathrm{t}$-table.

Tabel 13. The results of the significant coefficient test of the influence of $X 3$ on $Y$

\begin{tabular}{|c|c|c|c|c|c|}
\hline \multirow[b]{2}{*}{ Influence } & \multirow{2}{*}{$\begin{array}{l}\text { Unstd. } \\
\text { Koefesien }\end{array}$} & \multirow[b]{2}{*}{$\mathrm{T}_{\text {count }}$} & \multicolumn{3}{|l|}{$\mathrm{t}$-table } \\
\hline & & & $\begin{array}{ll}10 & \text { per } \\
\text { cent }\end{array}$ & $\begin{array}{l}5 \text { per } \\
\text { cent }\end{array}$ & $\begin{array}{l}1 \\
\text { percent }\end{array}$ \\
\hline $\mathrm{X}_{3}$ on $\mathrm{Y}$ & 0.171 & $1.672 *$ & 1.66 & 1.98 & 2.62 \\
\hline
\end{tabular}

Information: $* * *=$ very significant at the 10 percent level

Table 13 above shows that the coefficient value of job satisfaction on lecturer organizational commitment is 0.171 with a $t$-count value of 1.672 , which is greater than the t-table value for the 10 per cent significance level score1.66. Because the $t$-table value is greater than the $t$-count value, $\mathrm{HO}$ is rejected, which means that emotional intelligence has a positive and significant effect on lecturers' organizational commitment at the Open University in Indonesia. All hypotheses in this study were accepted and proven.

The results showed that organizational culture, emotional intelligence, and job satisfaction were positively and significantly related to organizational commitment. Organizational Culture is the most potent predictor that can affect organizational commitment, followed by Job Satisfaction and Open University's lecturers' emotional intelligence.

From the results of the first hypothesis test, it was concluded that, statistically, there was a positive and significant relationship between organizational culture variables and lecturers' organizational 


\section{International Journal of Business Management and Economic Review}

Vol. 4, No. 06; 2021

ISSN: 2581-4664

commitment. This means that the more conducive the organization's organizational culture, the higher the level of commitment of the lecturer organization (Ghina, 2012). The critical role of organizational culture in growing lecturer commitment is also found by Acar (2012). More specifically, Acar (2012) found that organizational culture that emphasizes strong emotional attachments, such as fraternal relations, has a strong relationship with affective commitment. Meanwhile, an organizational culture that emphasizes the provision of facilities and services to develop themselves has a more excellent relationship with normative commitment. According to Acar (2012), regarding his research results, organizations need to create a culture that emphasizes aspects of flexibility and discretion. This is because a flexible culture and encourages the emergence of collective behaviour can foster lecturer commitment to the organization.

There was a positive and significant relationship of job satisfaction variables to the organizational commitment of lecturers. Thus, it can be stated that the higher the level of job satisfaction of lecturers, the stronger the commitment to the organization. The findings are in line with the study results by Tahere, Zahra, Fateme, \& Asma (2012), which found a positive relationship between job satisfaction variables and the commitment of lecturers' organizations. Even among the variables, he observed, Tahere et al., (2012) found that a tremendous amount of job satisfaction was related to the formation of a lecturer's organizational commitment. Satisfied workers provide economic benefits to the organization in cost reduction, increased peace in the workplace, low levels of depression, and a small number of absences. With the creation of conducive working conditions like this, the strengthening of employee commitment to the organization tends to be more generous. The study findings that found a positive relationship of job satisfaction with lecturers' organizational commitment are supported by (Anari, 2012).

In this case, Anari (2012) concluded that organizational commitment is a function of the work capacity of lecturers. (Anari, 2012) emphasized several vital aspects to increase the job satisfaction of lecturers, including salary, conditions of colleagues, leaders, and other factors related to work. From the second hypothesis test results, it was concluded that, statistically, there was a positive and significant relationship between the variables of emotional intelligence on the organizational commitment of lecturers. Simply stated, this can be interpreted by the higher level of emotional intelligence possessed by the lecturer, the higher the level of commitment of the lecturer to the organization. Emotional intelligence can be interpreted as a person's ability to understand, recognize, feel, manage one's feelings and those of others, and be able to apply them personally and socially. Because of their excellent ability to manage their emotional condition, lecturers with a high level of emotional intelligence will be better able to deal with the demands of work (Shafiq \& Rana, 2016).

Furthermore, a positive relationship between emotional intelligence variables on organizational commitment occurs because of their excellent ability to control emotions. This is important because, in daily life, organizations must face various kinds of difficulties and challenges. Lecturers with high emotional intelligence tend not to blame organizations for their dissatisfaction and perceived imbalances. On the contrary, his ability to manage emotions properly helps him find a solution for any organizational problems. Therefore, by itself, a high level of emotional intelligence will direct lecturers to be more able to commit to the organization. 
International Journal of Business Management and Economic Review

Vol. 4, No. 06; 2021

ISSN: 2581-4664

\section{CONCLUSION}

The result shows that organizational culture, emotional intelligence, and job satisfaction have a positive and significant influence on the organizational commitment of lecturers; this study suggests the need for an Open University to develop a system of organizational culture, emotional intelligence of lecturers, and job satisfaction on an ongoing basis so that the formation of a more substantial organizational commitment to lecturers can be realized. Besides, from the outset, organizations must include EQ criteria, or emotional intelligence as criteria for admission of new lecturers or as criteria in promoting one's position, in addition to their technical and managerial abilities. For managerial implication, to grow an organizational commitment of lecturers, organizations need to pay attention to lecturers' conditions of job satisfaction by making improvements to aspects related to work, includes work characteristics of the work itself, remuneration, and working environment conditions, both physical and non-physical. For example, one of them relating to the elements of the work itself, organizations can carry out job enrichment policies through job rotation policies periodically to lecturers.

\section{REFERENCES}

Acar, Z. (n.d.). Organizational Culture, Leadership Style, and Organizational Commitment in Turkish Logistics Industry. Social and Behavioral Sciences, 58, 217 - 226.

Allen, N. J., \& Meyer, J. P. (1990). The measurement and variables associated with affective,continuance and normative commitment to the organization. Journal of Occupational Psychology, 63, 1-18.

Allen, P., Townsend, J., Dempster, P., Wright, J., Hutchings, A., \& Keen, J. (2012). Organizational Form as a Mechanism to Involve Staff, Public and Users in Public Services: A Study of the Governance of NHS Foundation Trusts. Social Policy and Administration, 46(3), 239-257. https://doi.org/10.1111/j.1467-9515.2011.00820.x

Anari, N. (2012). Teachers: Emotional intelligence, job satisfaction, and organizational commitment. Journal of Workplace Learning, 24, 256-269. https://doi.org/10.1108/13665621211223379

Beer, M. (2009). High Commitment, High Performance: How to Build a Resilient Organization for Sustained Advantage.

Eisenberger, R., Fasolo, P., \& Davis-LaMastro, V. (1990). Perceived Organizational Support and Employee Diligence, Commitment, and Innovation. Journal of Applied Psychology, 75(1), 51-59. https://doi.org/10.1037/0021-9010.75.1.51

Ghina, A. (2012). The Influence of Corporate Culture on Organizational Commitment: Case Study of Civil Government Organizations in Indonesia. International Journal of Applied Science, 1(2). Radosavljevic, Z., Cilerdzic, V., \& Dragic, M. (2017). Employee organizational commitment. International Review, (1-2), 18-26. https://doi.org/10.5937/intrev1702018r

Robbins, S. P., \& T, J. (2011). Organizational Behavior. New Jersey: Pearson Prentice Hall.

Shafiq, M., \& Rana, R. A. (2016). Relationship of Emotional Intelligence to Organizational Commitment of College Teachers in Pakistan. Eurasian Journal of Educational Research.

Taghipour, A., \& Dezfuli, Z. K. (2013). Innovative Behaviors: Mediate Mechanism of Job Attitudes. Procedia - Social and Behavioral Sciences, 84, 1617-1621. https://doi.org/10.1016/j.sbspro.2013.07.001 
International Journal of Business Management and Economic Review

Vol. 4, No. 06; 2021

ISSN: 2581-4664

Tahere, N., Zahra, G. T., Fateme, D., \& Asma, Y. J. (n.d.). Investigating the Effect of Job Experience, Satisfaction, and Motivation on Organizational Commitment Case Study: The Nurses of Ghaem Hospital in Mashhad. Research Journal of Recent Studies.

Utami, A. F., Bangun, Y. R., \& Lantu, D. C. (2014). Understanding the Role of Emotional Intelligence and Trust to the Relationship between Organizational Politics and Organizational Commitment. Procedia - Social and Behavioral Sciences, 115(Iicies 2013), 378-386. https://doi.org/10.1016/j.sbspro.2014.02.444 